\title{
The Impact of Agricultural Socialized Services to Promote the Farmland Scale Management Behavior of Smallholder Farmers: Empirical Evidence from the Rice-Growing Region of Southern China
}

\author{
Baozhong Cai ${ }^{1}$, Fang Shi ${ }^{2}$, Yuangji Huang ${ }^{1}$ and Meseret Abatechanie ${ }^{1, *}$ \\ 1 Research Institute of Rural Revitalization, Hunan University of Science and Engineering, \\ Yongzhou 425199, China; caibaozhong3245@huse.edu.cn (B.C.); hs326@126.com (Y.H.) \\ 2 School of Economics, Hunan Agricultural University, Changsha 410128, China; sff5656@163.com \\ * Correspondence: abatemeseretchanie3407@huse.edu.cn; Tel.: +86-15773158953
}

\section{check for}

updates

Citation: Cai, B.; Shi, F.; Huang, Y.;

Abatechanie, M. The Impact of

Agricultural Socialized Services to

Promote the Farmland Scale

Management Behavior of

Smallholder Farmers: Empirical

Evidence from the Rice-Growing

Region of Southern China.

Sustainability 2022, 14, 316.

https://doi.org/10.3390/su14010316

Academic Editor: Hossein Azadi

Received: 4 November 2021

Accepted: 18 December 2021

Published: 28 December 2021

Publisher's Note: MDPI stays neutral with regard to jurisdictional claims in published maps and institutional affiliations.

Copyright: (C) 2021 by the authors. Licensee MDPI, Basel, Switzerland. This article is an open access article distributed under the terms and conditions of the Creative Commons Attribution (CC BY) license (https:// creativecommons.org/licenses/by/ $4.0 /)$.

\begin{abstract}
Farmland scale management (FSM) is an essential strategy to establish an appropriate management scale for agricultural production, enhance smallholder farmer production efficiency, and improve the utilization rate of farmland. The Chinese government promotes farmland transfer as a tool to establish modern and moderate-scale agriculture. However, farmers remain unable to afford agricultural services and inputs required for appropriate FSM after farmland is transferred-in. This paper aims to examine the impact of agricultural socialized services (ASSs) on the FSM behavior of smallholder farmers through farmland transfer. A theoretical framework for the farmer household production aspect of this relationship is developed. A weighted least squares (WLS) model is applied to empirically examine smallholder farmers' decisions to expand the scale of farmland induced by the promotion of ASSs based on data collected from 741 households in 2020 in the rice-growing region of southern China. The findings reveal that ASSs have a positive and significant impact on small farmers' FSM. Small farmers' behavior regarding farmland transfer is affected positively by the promotion of ASSs. The increase of ASSs encourages small farmers to transfer-in more farmland. However, the impact of ASSs on various steps of agricultural practice varied according to the FSM of smallholder farmers. Our findings imply that the government should take the development of ASSs as one of the main methods for promoting the establishment of moderate and large-scale agriculture and rural revitalization. Strengthening policies and financial support for both private and public ASS providers through financial innovation subsidies and preferential tax policies will help smallholder farmers reduce input costs and increase the scale of production and profits. The findings of this paper will provide a scientific basis and reference for the development of moderate-scale agriculture and rural revitalization.
\end{abstract}

Keywords: agricultural socialized services; productivity; farmland scale management; smallholder farmers; moderate-scale agriculture

\section{Introduction}

The debate on the most appropriate size for a farm is ongoing [1-4]. Small-scale agriculture is promising when it comes to protection of the natural environment [5], whereas large-scale agriculture provides greater quantities of food for a growing population. In recent years, countries with a preference for small-scale agriculture have shown an interest in moving from small-scale to moderate and large-scale agricultural production through applying agricultural economies of scale [6,7]. The transfer of agricultural labor to rural offfarm industries and urban areas promotes farmland transfer among smallholder farmers, resulting in land consolidation through which moderate and large-scale farmlands are emerging [8]. However, farmland scale management (hereafter FSM) (farmland scale management refers to the form of land management to optimize socioeconomic benefits by 
changing the farmland area. Smallholder farmers adjust the size or scale of their farmland through transferring-in farmland from another farmer) alone cannot lead smallholder farmers to operate moderate and large-scale agriculture. The scale of other agricultural inputs, such as agricultural machinery, should be upgraded and matched with the scale of farms [9]. Smallholder farmers cannot purchase large-scale agricultural machines and other inputs suitable for emerging large and moderate scale farmlands. This prevents smallholder farmers from getting involved in the farmland transfer market and hinders the scaling-up of agricultural operations. Thus, a new model of agricultural input services urgently needs to be established.

China is on the way to establishing modern and moderate-scale agriculture by practicing FSM [6,10]. Besides encouraging agricultural labor transfers into off-farm employment, the government promotes farmland transfer to realize moderate-scale agriculture among smallholder farmers. Farmland transfer in China is the transfer of a parcel of farmland from one farmer (transfer-out) to another farmer (transfer-in) for two basic reasons. Firstly, when farmers move away to urban areas or rural-off farm industries for non-agricultural employment opportunities, they transfer-out their farmland [8,11]. Secondly, when farmers get old, the benefits to be obtained through transferring their farmland to others are greater than those derived from managing their farmland themselves [12]. In China, most old farmers have low skills and knowledge about modern farming practice (e.g., they cannot utilize farm machines and have limited abilities when it comes to fertilizer application). Moreover, the price of rice is cheap and the financial benefit obtained from rice farming is lower. Therefore, old farmers prefer to rent out their farmland to farmers who are capable of obtaining higher financial benefit through scaling up the size of their farmland and applying modern farming practices. At present, there is no special support policy for old farmers, which is similar to the situation in Japan and other countries.

Farmland transfer in China is highly promoted by the government. This is because the nature of China's agriculture is small-scale. The farmland transfer market is fully guided by village government officials. The government collects all the available information on farmland and puts it into the online market system. Those farmers who would like to rent-in the farmland can obtain the information from the system. In 2019, the average farmland size was 0.56 hectares (according to our research, the operating farmland area of smallholder farmers in China is below $26 \mathrm{mu}$ (1.733 hectares). The average farmland size in southern China is $7.276 \mathrm{mu}(0.485 \mathrm{ha})$. Date on average farmland in China in 2019 retrieved from the national agricultural statistical data of Ministry of Agriculture and Rural Affairs in China), which is far less than the world average. When the household responsibility system come into effect in the main rural reform period of the early 1980s, communal farmlands were equally shared between rural households [13]. This resulted in substantial farmers with small and fragmented farmlands. The accumulation of agricultural labor in rural areas restricted the effort to cultivate moderate and large farms [14]. Farmers have been forced to get involved in intensive farming systems which put huge pressures on the land and lead to farmland fragmentation and degradation [15]. Nonetheless, with small farmers, China has achieved huge agricultural productivity over the last 40 years [16].

During the last four decades, urbanization and the growth of rural off-farm industries have caused the mass outflow of rural labor for employment opportunities [11,17]. This has created space for farmland transfer and promoted the establishment of an appropriate scale of farmland [18]. Since China promoted the reform of the "separation of three rights" (China's farmland system divides farmland property rights into three types. The ownership right, where it belongs to the village collective; the contracting right, where it belongs to the members of the village collective; the management right, where farmland can be leased to others to obtain rent or other income) of farmland in 2014, researchers have conducted extensive discussions on farmers' FMS behavior and its influencing factors. The factors affecting farmers' FSM behavior decisions can be divided into two categories. First, the internal factors for farmers mainly include farmers' human capital [19], social security [20], and part-time 
employment [18]. Second, there are the external factors, such as the economic development level [21], marketization of farmland transfer [22], and security of property rights [23].

Farmland transfer alone cannot induce the establishment of moderate-scale agricultural operations. Farmland transfer should be integrated simultaneously with improvement in the scale of agricultural input services [24]. Even though smallholder farmers have an opportunity to cultivate moderate-scale farms, they cannot afford inputs, such as agricultural machines, which are suited to the size of the farmland. In China, agricultural socialized services (hereafter ASSs) are an agricultural business model in which cooperatives, private agricultural service firms, and self-employed agricultural service agents provide agricultural input services (such as machine-rent and labor-hire services) to smallholder farmers [25]. ASSs represent the specialization and marketization of agricultural input services for smallholder farmers [26]. The cost of ASSs is expected to be lower than the farmers' capability of providing the services by themselves. However, in some areas, the cost of ASSs is higher than the smallholder farmers' capability to provide for themselves. This raises the question of whether ASSs have an influence on the farmland transfer behavior of smallholder farmers and facilitate the development of moderate-scale agriculture in China.

ASSs are generally regarded as a bridge to shifting smallholder farmers into operating moderate and large-scale agriculture. They can effectively promote farmland transfer and coordination to achieve large-scale farmland management [27-29]. Farmland-scale and service-scale operations promote each other. The process of agricultural modernization as carried out in China is not characterized by competitive but by win-win relationships [24]. Moreover, ASSs can realize agricultural scale operations without changing the household management system and land property ownership [30], which is a good way to resolve the contradiction between household operation and the scale of agricultural mechanization [31].

Researchers have carried out an empirical analysis of how FSM is affected by ASSs. For instance, [32] investigated the interaction between agricultural machinery investment and land scale using state-level data from the United States. They found that one-third of profitable farm owners expanded their farmland under their management through leasing due to the use of agricultural machinery. In [33], it was reported that the unified provision of irrigation services, tractor farming services, and pest control services in a village can significantly promote land scale management, while [34] revealed that the purchase of agricultural machinery and socialized services in rice production and harvesting have become key factors affecting farmers' land transfer behavior. The authors also revealed that rice transplanting and drying have little impact on farmers' land transfer. This indicates that the effect of ASSs on the FSM of small farmers varied between various agricultural practices. The authors of [35] found that the availability of ASSs promoted the development of farmers' FSM operations by alleviating constraints on labor, technology, and other resource endowments.

Previous studies have shortcomings in that they focus on whether purchasing was the best way to measure ASSs and their impact on farmland transfer behavior among smallholder farmers when it is difficult to accurately measure development levels. Moreover, it is easy to sink into serious endogenous problems in the empirical analysis. In addition, existing studies have ignored an important fact regarding rice production in southern China. There are still a large number of artificial transplanting (artificial rice transplanting ASSs refers to the transplanting of seedlings from one rice farm to another, which is an important part of rice production in China) ASSs that the researchers have not addressed yet. In the study of ASSs, we cannot consider only agricultural machinery services to the exclusion of artificial socialized services.

This paper attempts to supplement the existing literature in two aspects. Firstly, focusing on the smallholder (in this paper, smallholder farmers refer to rice-farmers who are cultivating a range of farmlands below $26 \mathrm{mu}(1.733 \mathrm{ha})$ ) farmers in the rice region of southern China, this paper takes the development level of ASSs in the villages where the smallholder farmers are located as the relevant variable to avoid the endogeneity (in 
the process of quantitative analysis, due to the mutual influence between two variables, endogenous problems will occur. This will affect the accuracy of the analysis and thus, measures must be taken to avoid it) of the model analysis. We empirically test the farmland management area and farmland transfer behavior of the smallholder farmers to make the analysis in-depth and complete. Second, in terms of research methods, using microsurvey data and weighted least squares (WLS), this paper considers the possibility of simultaneous decision making between different production and management decisions of smallholder farmers (i.e., the purchase of ASSs and farmland transfer-in). Moreover, this study contributes to the literature by providing policymakers with specific knowledge on how the availability of ASSs could affect the FSM operation of smallholder farmers when moving into moderate and large-scale agricultural production.

The paper is organized as follows. First, we develop the theoretical framework for analysis and propose our hypotheses on the influence of ASSs on the FSM operation of smallholder farmers. Second, we summarize the survey methodologies and the data obtained from the smallholder farmers. Third, we evaluate the empirical findings, after which we provide a summary of the paper's contributions to the agricultural economy of scale literature, and finally highlight the broad implications for contemporary debates on ASSs in Section 4.

\section{Theoretical Analysis and Development of Hypotheses}

\subsection{ASSs and the Change in Input Structure for Agricultural Production Factors}

The promotion of urbanization and the rapid development of secondary and tertiary industries leads to an increase in real wage income. This encourages a large number of young and middle-aged people from the rural labor force to transfer into urban areas, resulting in the extreme differentiation of rural and urban populations, with more elderly people, women and children, and a reduced young male labor force in the former [36]. The elderly and women are now the main representatives of agricultural labor. Moreover, China's demographic dividend has gradually disappeared [37], and the rapid rise of labor costs have gradually increased the cost of agricultural production. According to a theory of induced technological change in agricultural production proposed by [38], changes in factor prices caused by scarcity of resources will induce technological progress and factor substitution. Land and labor are the basic input elements of agricultural production, and the cost of the agricultural labor force is increasing. Farmers, therefore, tend to reduce their investment in agricultural labor to maintain an operational scale and maintain their income level. Thus, farmers, tend to replace human labor with agricultural machines to reduce the cost of agricultural production.

The advancement of agricultural technology, especially regarding the high efficiency of agricultural production brought about by the improvement of the level of mechanization, makes agricultural machinery the best choice for labor substitution. Researchers have also revealed that there is a strong substitution relationship between agricultural machinery and labor [39]. Figure 1 shows a model of the agricultural machinery and labor substitution process to indicate factor substitution.

$\mathrm{E}^{*}{ }_{0}$ represents the initial possibility curve of technological innovation. When the price ratio of machinery to labor is aa', a certain technology (such as machinery) $\mathrm{e}_{0}$ is invented. At this time, the minimum cost equilibrium point is M. At this point, labor and the input of mechanical elements are at the optimal ratio. When the price ratio of machinery to labor changes from aa' to $\mathrm{bb}^{\prime}$, the machinery reaches a new development and progress level and labor costs rise. Point $\mathrm{N}$ is the new equilibrium point and indicates that machinery will replace labor to a greater extent. 


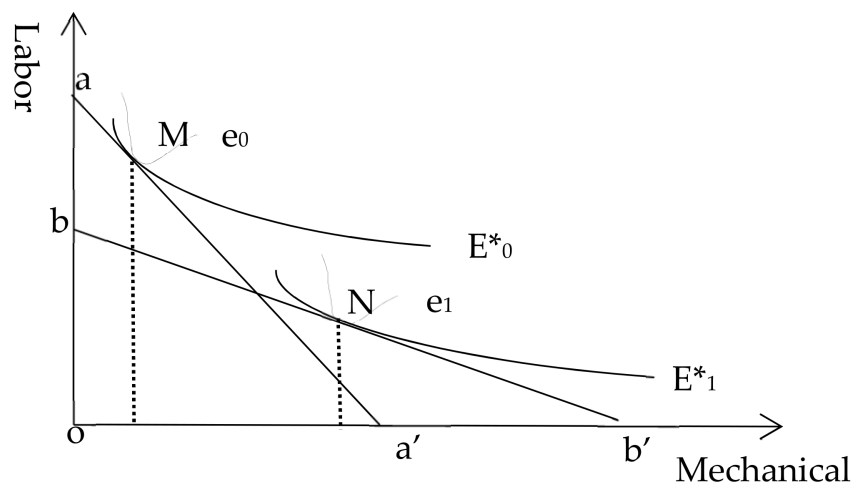

Figure 1. Model diagram showing the substitution of agricultural machinery for labor. Source: Created by the author.

\subsection{Changes in the Input Structure of Agricultural Production Factors and Agricultural Scale Management}

In the process of urbanization and development of secondary and tertiary industries, the demand for labor has risen and labor resources are relatively scarce. This leads to a rise in labor wages and changes in the capital-labor factor input ratio. As a result, the substitution of labor has become an important driving force in farmland transfer. On the other hand, the advancement of agricultural machinery and technology promotes the application of agricultural machinery and improves the efficiency of agricultural production, thereby changing the ratio of capital-labor factor inputs. Thus, farmland transfer and the scale of operation have become matters of rational choice for agricultural operators. This paper constructs the theoretical analysis framework for agricultural machinery and farmland transfer as shown in Figure 2.

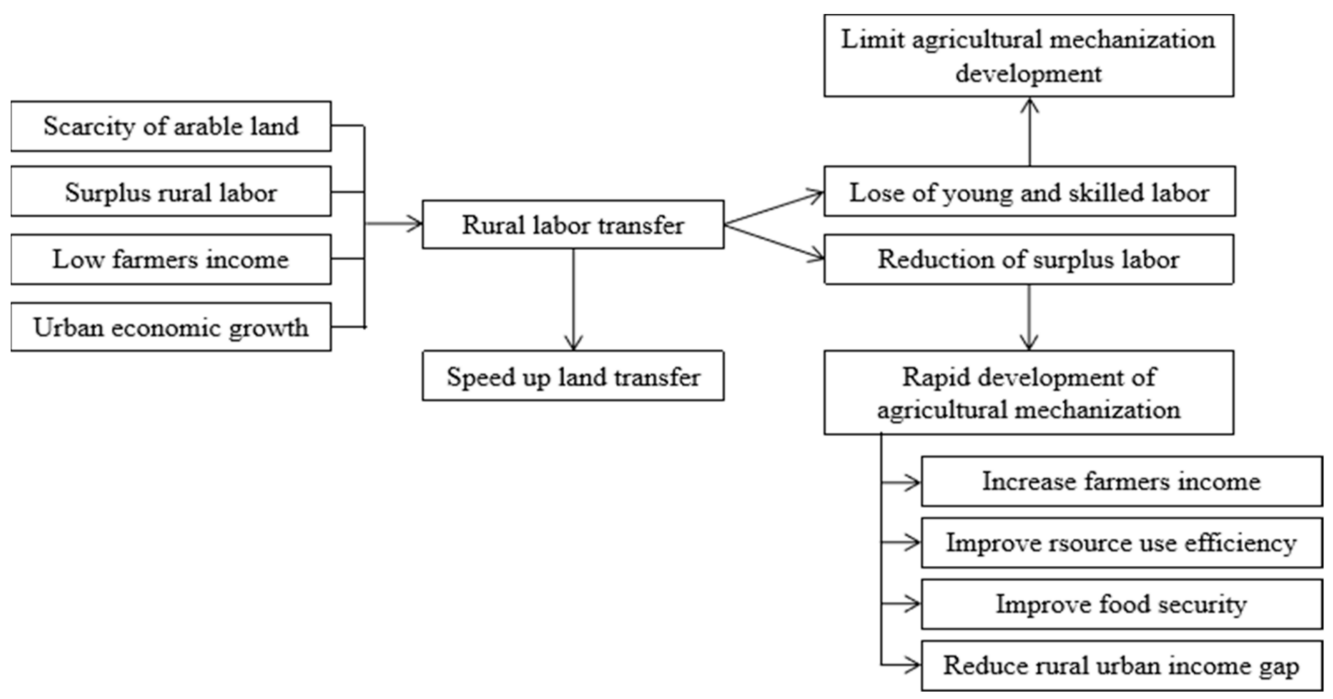

Figure 2. The relationship between agricultural mechanization, rural labor, and farmland transfer. Source: The authors designed the diagram of the theoretical framework based on the information available in the above analysis.

\subsection{Agricultural Socialized Services and Agricultural Scale Operations}

In terms of economic benefits, agricultural machinery improves agricultural production efficiency. However, the limited economic ability and small-scale agricultural operation of small farmers means that they often cannot afford the purchase cost of large agricultural machinery [40]. Compared with the high cost of purchasing agricultural machines, the ASS has gradually developed under the conditions of marketization and socialization to reduce 
agricultural investment. Agricultural mechanization has become a common demand from farmers of different scales [41] and has become an important choice when it comes to realizing agricultural modernization with Chinese characteristics.

Affected by rapid urbanization and the aging of its farmers, China's agricultural labor force is rapidly shrinking. Agricultural machine replacement is the best solution to continue China's agricultural development. Currently, ASSs in southern China are mainly agricultural mechanization services, and though the cost of ASSs are rising, they are still affordable. There are specialized farm machinery service providers for farmers in southern China who provide machine services on a mobile basis throughout the region. These farmers are able to purchase the machines for themselves and provide tillage, transplanting, and harvest services to other smallholder farmers. There are problems associated with accessing ASSs as a result of the high demand for ASSs during the peak agricultural (i.e., sowing and harvesting) seasons. Therefore, increasing the availability of farm machinery during peak agricultural seasons should be increased and the costs of ASSs should be reduced to some extent.

ASSs can solve the problem of heavy physical labor and improve agricultural production efficiency, reduce the input cost of agricultural production, and improve the comprehensive income of rural households. Encouraging farmland transfer to achieve moderate-scale agricultural operation is the most satisfying choice for farmers. Planting rice in southern China will make little profit if the planting area is very small, but it will occupy the main labor force of the family. With the help of ASSs, farmers can operate a much larger area of farmland than their own contracted farmland. Therefore, farmers are highly encouraged by farmland transfer to maximize their received benefits via the adjustment of the size of their farms. In terms of institutional changes in perspective, the service outsourcing mechanism for agricultural practices promotes moderate scale management of farmland operations [33]. As a new system of allocating resources, agricultural service outsourcing shows strong evidence of the institutional changes in agricultural production. It is believed that with the help of agricultural service outsourcing, farmers will gradually change the traditional farmland management model and realize large-scale agricultural operations with Chinese characteristics (operations with Chinese characteristics refers to operating under the land system arrangement whereby land rights are split into three. Farmland transfer is used to expand the scale of operation, rather than buying and selling land).

\subsection{Development of Research Hypotheses}

Based on the above theoretical analysis, ASSs introduce advanced production factors into the production behavior of small farmers. Moreover, they improve agricultural production efficiency, liberate agricultural labor to increase productivity, and realize the substitution of capital factors for labor factors. The purchase of ASSs rationalizes the appropriateness of farmland size and agricultural machines for better productivity through reducing farmland fragmentation and agricultural labor inefficiency. The development of ASSs promotes farmland transfer and concentrates separated and scattered lands, thereby enhancing land consolidation. In China, arable land cannot be bought and sold. Agricultural socialized services allow the service providers to specialize in specific services (e.g., tillage and harvesting services). Moreover, ASSs reduce production costs for farmers and induce technological changes in agricultural production. Smallholder farmers transfer-in farmland from other farmers to expand their scale of operation and increase the marginal income from agricultural production.

ASSs are diversified across the different steps of agricultural practice. The impact difference is due to the differences in the physical and temporal needs of the labor force in different agricultural production practices. The impact is highest on rice harvesting because a larger labor force is needed and takes more time compared with other agricultural production practices. This difference may lead to differences in the scale of farmland management. ASSs save more energy and time and enhance the quality of agricultural production practices (reducing the loss of agricultural input and output). This directly 
encourages smallholder farmers to transfer-in farmland. However, there is no direct effect of ASSs on farmers who transfer-out their farmlands. The presence of those receiving farmland indicates the existence of those giving away their farmlands. This paper examines the overall impacts of ASSs on the FSM of smallholder farmers through farmland transfer. We then select the ASSs of the four main steps of agricultural practices; tillage, sowing, crop protection, and harvesting, to investigate their impacts on the FSM of small farmers. Finally, we take the small farmers' decision-making behavior to analyze the specific impact of ASSs as a reference for robustness analysis. Based on the above theoretical analysis, we propose the following hypotheses:

Hypotheses 1. Increasing the accessibility of ASSs has a positive impact on smallholder farmers' FSM operations.

Hypotheses 2. The impact of ASSs differs between tillage, transplanting, crop protection (including pesticide, herbicide, and fertilizer application), and harvesting on the FSM of smallholder farmers.

Hypotheses 3. ASSs will affect the farmland transfer behavior of smallholder farmers, including both farmland transfer-in and transfer-out.

\section{Data and Methods}

\subsection{Data Collection}

Data were collected in July and August 2020 in the Hunan, Jiangxi, and Zhejiang provinces of south China. These provinces are the rice-producing bases of China and are responsible for more than $25 \%$ of national rice production. In the selection of sample households, the regional development level, geographical location, and relevant agricultural natural resource endowment were considered. The sample villages were determined using a combination of stratification (counties and districts) and random sampling (village and towns). However, the selection of farmers with farms in these villages was conducted using random sampling selection. Representative counties for the major rice-planting areas in the three provinces were selected. Figure 3 show the map of the study area. In Hunan province, 282 households were selected in Hengyang, Yanling, and Yiyang counties. In Jiangxi province, 334 households were selected in Wannian, Poyang, and Yugan counties. In Zhejiang province, 125 households were selected in Qingyuan and Xiangshan counties. In total, we obtained 741 households in eight counties to construct the dataset.

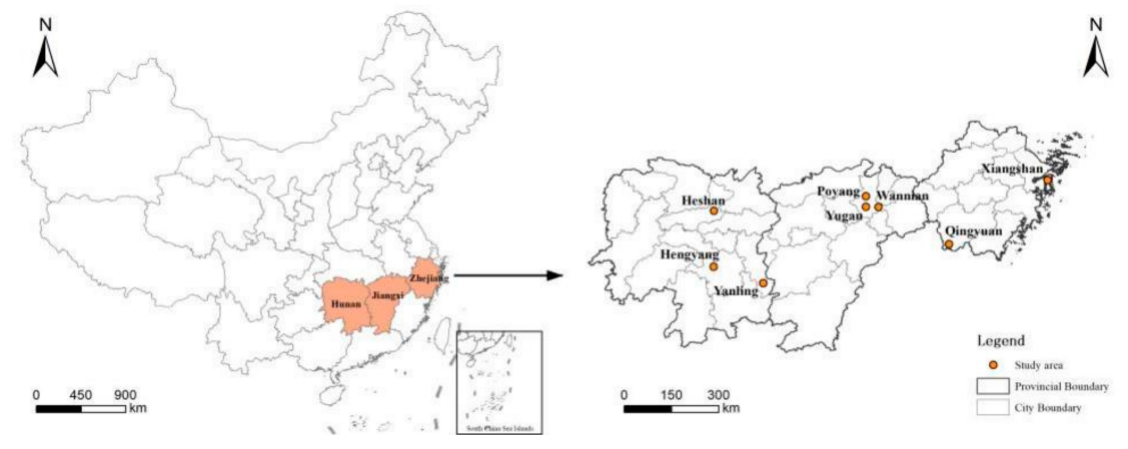

Figure 3. Map of the surveyed area. Source: Created by the author.

The controlled variables required were data on small-scale rice farmers' characteristics, family characteristics, farmland characteristics, and village characteristics. A total of 800 questionnaires were distributed, and 741 valid samples met the requirements of this study, with an effective rate of $92.63 \%$.

The questionnaire formulation, pre-investigation, and finally the editing of the questionnaire were carried out to ensure that the content was clear, properly understood, and accepted by farmers in the face-to-face interviews. The interviews with farmers were conducted by a group of 12 research experts who were familiar with our research team. 
Before the survey, to prove the trustworthiness and reliability of the survey data, the experts undertook training to ensure that the members fully understood the relevant issues in the questionnaire. The survey targeted rice farmers who had transferred farmland (in and out) in the village. The raw data were handled and analyzed using stata14 to facilitate analysis.

\subsection{Description of Variables}

\subsubsection{Dependent Variables}

Table 1 presents the definitions of the variables and descriptive statistical analyses. The dependent variables in this paper are the operation scale of small farmers, small farmers' behavior regarding farmland both transferred-in and transferred-out, small farmers' behavior regarding only farmland transferred-in, and small farmers' behavior of farmland only transferred-out. According to the descriptive statistical analysis of variables (see Table 1), the average farmland scale of small farmers in Hunan, Jiangxi, and Zhejiang is $7.275 \mathrm{mu}$, and the overall operation scale is small. The proportion of small farmers showing farmland transfer behavior was $52.45 \%, 40.53 \%$ of which came under the category of farmland transferred-in behavior.

Table 1. Variable definitions and statistical description.

\begin{tabular}{|c|c|c|c|c|c|}
\hline & Variable Category & Variables & Definition & Mean & S. D \\
\hline \multirow{2}{*}{$\begin{array}{l}\text { Dependent } \\
\text { variable }\end{array}$} & \multirow{2}{*}{$\begin{array}{c}\text { Scale management } \\
\text { behavior }\end{array}$} & $\begin{array}{l}\text { Management scale of } \\
\text { smallholder farmers }\end{array}$ & $\begin{array}{l}\text { Actual cultivated land } \\
\text { management area of } \\
\text { smallholder farmers (MU) }\end{array}$ & 7.276 & 6.363 \\
\hline & & $\begin{array}{l}\text { Is there any cultivated } \\
\text { land transfer in }\end{array}$ & Yes $=1 ;$ No $=0$ & 0.405 & 0.491 \\
\hline \multirow{5}{*}{$\begin{array}{l}\text { Independent } \\
\text { variable }\end{array}$} & \multirow{5}{*}{$\begin{array}{c}\text { Agricultural } \\
\text { socialized service }\end{array}$} & $\begin{array}{c}\text { Development level of } \\
\text { local ASS }\end{array}$ & $\begin{array}{l}\text { Actual expenditure of ASS } \\
\text { for producing one season of } \\
\text { rice per mu in the village } \\
\text { where the smallholder } \\
\text { farmers are located (yuan) }\end{array}$ & 266.904 & 61.317 \\
\hline & & Cultivated land link & $\begin{array}{l}\text { Proportion of households } \\
\text { purchasing services in } \\
\text { cultivated land in villages } \\
\text { where smallholder farmers } \\
\text { are located }\end{array}$ & 0.783 & 0.153 \\
\hline & & Planting link & $\begin{array}{l}\text { Proportion of households in } \\
\text { the village where } \\
\text { smallholder farmers are } \\
\text { located to purchase services } \\
\text { during seedling } \\
\text { transplanting }\end{array}$ & 0.342 & 0.189 \\
\hline & & Plant protection link & $\begin{array}{c}\text { Proportion of smallholder } \\
\text { farmers' villages purchasing } \\
\text { services in plant protection } \\
(\%)\end{array}$ & 0.193 & 0.152 \\
\hline & & Harvesting link & $\begin{array}{l}\text { Proportion of smallholder } \\
\text { farmers' villages in }^{\prime} \\
\text { purchasing services during } \\
\text { harvesting }(\%)\end{array}$ & 0.821 & 0.178 \\
\hline \multirow{3}{*}{$\begin{array}{l}\text { Control } \\
\text { variable }\end{array}$} & \multirow{3}{*}{$\begin{array}{c}\text { Individual } \\
\text { characteristics }\end{array}$} & Age & $\begin{array}{c}\text { Actual age of respondents } \\
\text { (years) }\end{array}$ & 61.901 & 9.417 \\
\hline & & Education level & $\begin{array}{l}\text { Education years of } \\
\text { respondents (years) }\end{array}$ & 3.979 & 3.092 \\
\hline & & $\begin{array}{l}\text { Work experience outside } \\
\text { hometown }\end{array}$ & $\begin{array}{l}\text { Years of migrant work of } \\
\text { respondents (years) }\end{array}$ & 3.661 & 1.022 \\
\hline
\end{tabular}


Table 1. Cont.

\begin{tabular}{|c|c|c|c|c|}
\hline Variable Category & Variables & Definition & Mean & S. D \\
\hline \multirow{4}{*}{$\begin{array}{c}\text { Family } \\
\text { characteristics }\end{array}$} & Population structure & $\begin{array}{l}\text { Number of labor force/total } \\
\text { number of households (\%) }\end{array}$ & 0.598 & 0.332 \\
\hline & Income level & $\begin{array}{l}\text { Total household income in } \\
2019(10,000 \text { yuan })\end{array}$ & 93506.88 & 103963.6 \\
\hline & $\begin{array}{c}\text { Proportion of } \\
\text { agricultural production } \\
\text { income }\end{array}$ & $\begin{array}{l}\text { Agricultural income/total } \\
\text { household income in } 2019 \\
(\%)\end{array}$ & 0.287 & 0.334 \\
\hline & Human capital & $\begin{array}{l}\text { Number of college students } \\
\text { in family members (person) }\end{array}$ & 0.326 & 0.469 \\
\hline \multirow{3}{*}{$\begin{array}{l}\text { Cultivated land } \\
\text { characteristics }\end{array}$} & $\begin{array}{l}\text { Degree of cultivated } \\
\text { land fragmentation }\end{array}$ & $\begin{array}{l}\text { Number of cultivated } \\
\text { plots/actual cultivated plots } \\
\text { (block/mu) }\end{array}$ & 1.211 & 1.363 \\
\hline & Cultivated land leveling & $\begin{array}{c}\text { Flat }=1 ; \text { A little slope }=2 \\
\text { Large slope }=3\end{array}$ & 1.813 & 0.788 \\
\hline & $\begin{array}{l}\text { Cultivated land fertility } \\
\text { status }\end{array}$ & $\begin{array}{l}1=\text { very poor; } 2=\text { poor; } 3= \\
\text { General; } 4 \text { = better; } 5=\text { very } \\
\text { good }\end{array}$ & 3.274 & 0.859 \\
\hline \multirow{3}{*}{$\begin{array}{c}\text { Village } \\
\text { characteristics }\end{array}$} & Geographical position & $\begin{array}{l}\text { Mileage from nearest } \\
\text { township government }(\mathrm{km})\end{array}$ & 5.619 & 4.047 \\
\hline & $\begin{array}{l}\text { Local cultivated land } \\
\text { transfer price }\end{array}$ & $\begin{array}{c}\text { Actual price of land } \\
\text { circulation in } 2019 \\
(\text { yuan } / \mathrm{mu})\end{array}$ & 436.782 & 83.926 \\
\hline & $\begin{array}{c}\text { Agricultural } \\
\text { infrastructure level }\end{array}$ & $\begin{array}{l}\text { Does the village have high } \\
\text { standard farmland } \\
\text { construction }{ }^{1} \text { ? } \\
\text { Yes }=1, \text { no }=0\end{array}$ & 0.360 & 0.480 \\
\hline
\end{tabular}

${ }^{1}$ In China, the construction of high-standard farmland has been carried out over the years as an agricultural project, which means that uneven farmland is sorted and flattened according to the standard and broken farmland is consolidated.

\subsubsection{Independent Variables}

This paper adopted ASSs that produce one season of rice per mu of land in the village where small farmers are located as its variable. This avoids endogeneity problems induced by farmers' green production behaviors and the purchase of agricultural services. If the expenditure on ASSs per unit area for each farmer is used directly as a variable, this will create serious endogeneity problems. Therefore, the average price of ASSs per unit area in the village where the farmer is located is used as a substitute. The amount of expenditure is used to measure the level of local ASSs. Therefore, the availability of the ASS is measured based on the cost of ASSs. The lower the cost of an ASS, the easier smallholder farmers can access it. Compared with the direct use of local availability indicators, such as the availability of ASSs, this better represents the development level of ASSs where farmers are located.

\subsubsection{Controlled Variables}

In accordance with the rational farmer behavior theory, this paper identified four controlled variables: the individual characteristics of farmers, family characteristics, farmland characteristics, and village characteristics. First, individual characteristics include the age, educational level, migrant work experience, and agricultural technology training experience of the farmers. Family characteristics consist of income level, family business type, and human capital. The farmland characteristics are composed of farmland area, farmland fragmentation degree, farmland leveling, and farmland fertility. The characteristics of the village mainly include the geographical location of the village and whether the local government has publicized agricultural green production policies in the village. 


\subsection{Model Specification}

In accordance with the household model of [42,43], this paper constructs a farm household production framework to analyze the impact of ASSs on FSM. In order to facilitate the analysis, it is assumed that the factor market faced by farmers is perfect and that the goal of maximizing farmers' utility is simplified to maximizing agricultural production profits. In addition, it is assumed that farmers only engage in agricultural production, without carrying out any off-farm employment. Moreover, the crop type isn't distinguished and the agricultural production function of farmers only includes agricultural socialized services and farmland scale operations.

The land resource endowment of the farmer is $\bar{A}$. In local farmland transfer markets, farmers can transfer their farmland. The actual farmland managed by the farmer is $A$, and the farmland rent-in is represented by $r$. In the ASS market, farmers can purchase ASS, and the value of ASS per area invested in agricultural production is $S$ and the price per area is $m$. Thus, the cost of purchasing ASS is $m S$. The unit price of the grain product is $p$. Therefore, farmers invest in ASS, and the optimal value of land $S^{*}, A^{*}$ can be transformed in order to solve the maximization problem. To ensure that the objective function has a maximum value, it is necessary to assume that the farmer's agricultural production function, $f(A, S)$ is strictly concave, i.e., $f_{S}>0, f_{A}>0, f_{S S}<0, f_{A A}<0$, and also:

$$
D=\left|\begin{array}{cc}
f_{S S} & f_{S A} \\
f_{A S} & f_{A A}
\end{array}\right|=f_{S S} f_{A A}-f_{S A}^{2}>0
$$

We set the farmer objective function as:

$$
\max _{S, A} \prod=p f(A, S) \quad m S \quad(A, \bar{A}) r
$$

The first-order condition is:

$$
\left\{\begin{array}{l}
p f_{S}=m \\
p f_{A}=r
\end{array}\right.
$$

A farmer's decision to invest in FSM and ASS to obtain the maximum profit needs to satisfy Equation (2). This shows that, at equilibrium state, the marginal output of households purchasing one unit of ASS should be equal to the price of unit ASSs. The net income of investing in one unit of farmland for agricultural production is equal to the rent per unit of transferred farmland. Since $f_{A}$ and $f_{S}$ are the functions of farmland input $A$ and ASS input $S$, respectively, the total differential of $A, S, m, r, p$ is obtained from Equation (2) as follows:

$$
\left\{\begin{array}{l}
p f_{S S} d S+p f_{S A} d A+f_{S} d p-d m=0 \\
p f_{A S} d S+p f_{A A} d A+f_{A} d p-d r=0
\end{array}\right.
$$

Solving Equation (3) can obtain the result:

$$
d A=\frac{1}{p\left(f_{A S} f_{A}-f_{A A} f_{S}\right)}\left[\left(p f_{A S} f_{S}-P f_{S S} f_{A}\right) d S+f_{A} d m-f_{S} d r\right]
$$

This paper only observes the impact of ASSs on the FSM; therefore, let $d m=d r=0$ and grain price $p=0$, then:

$$
\frac{d A}{d S}=\frac{f_{A S} f_{S}-f_{S S} f_{A}}{f_{A S} f_{A}-f_{A A} f_{S}}
$$

Equation (5) shows that if $f_{A S}>0$, then $\frac{d A}{d S}>0$, i.e., with the increase of ASS input, the FSM will expand.

If $f_{A S}<0, \frac{d A}{d S}<0$, then with the increase of investment in ASSs, the scale of farmland management will shrink. It can be seen that the direction of the impact of ASS inputs on the FSM depends on the positive and negative direction $f_{A S}$.

$f_{A S}$ represents the impact of changes in ASS inputs on the marginal output of farmland, reflecting the substitution or complementation of factors. ASSs and farmland are 
complementary factors of production. If technological progress is not taken into account, and when the input of farmland and other factors are at an equilibrium state, an increase in the input of ASSs will increase the relative scarcity of farmland and increase the marginal output of farmland. Achieving a new equilibrium state, the input of farmland will also increase, showing a situation where the input of ASSs and the input of farmland will increase and decrease simultaneously.

It can be seen that, since FSM and farmland are complementary elements, the increase in ASS input increases the marginal output of land, that is, $f_{A S}>0$, then $\frac{d A}{d S}>0$.

As a rational agricultural production and operation subject, farmers consider external constraints when deciding to expand the FSM. At this stage, the continuous development of ASSs provides sufficient service supply for agricultural production. Farmers can alleviate the original resource endowment of FSM restrictions through the reasonable matching of their production factors and external production factors to achieve moderate-scale operation. Therefore, it can be inferred theoretically that the increase of ASS investment provides an incentive to farmers to expand their farms. In this paper, we empirically test the above research hypothesis using microdata from the farmer level.

This paper has carried out an empirical analysis of the mechanism of ASSs affecting the appropriate FSM of small farmers in China. From the practical perspective, this paper examines how ASSs have impacts on the moderate scale operation of farmland. Moreover, the paper analyzes the structural differences in the impact of different types of FSM on farmland transfer. In the development of moderate-scale agriculture operations, changes induced by the impact of ASSs were empirically explored.

The data used in this paper are cross-sectional and do not have equal variance; thus, they violate the homoscedasticity assumption. The application of the ordinary least squares method (OLS) in this case will lead to the problem of heteroscedasticity, which will affect the scientific validity of the regression results. Thus, weighted least squares (WLS) are used to overcome the heteroscedasticity problem. Moreover, WLS regression is critical for concentrating on each specific area and gives greater weighting to the target variables. The main operating principle is that by weighting the ordinary least square method, it is possible to construct a model without a heteroscedasticity problem. The equation for weighted least squares (WLS) is written as follows:

$$
W_{i}=\frac{1}{\sigma_{i}}
$$

If the weighting is taken as read, then the matrix is written as follows:

$$
W=\left(\begin{array}{cccc}
w_{1} & 0 & \cdots & 0 \\
0 & w_{2} & \cdots & 0 \\
\cdots & \cdots & \cdots & \cdots \\
0 & 0 & \cdots & w_{N}
\end{array}\right)
$$

In addition, the OLS + robust standard error approach is used to handle heteroscedasticity. The robust standard error is an approach to analyze data without the biased standard errors of the OLS coefficient of heteroscedasticity, serving as a robust reference for model estimation results.

\section{Results and Discussion}

\subsection{The Impact of ASSs on Smallholder Farmers' FSM}

The impact of ASSs on the overall FSM of smallholder farmers is presented in Table 2. It can be seen that ASSs have a significant impact on the operating scale of small farmers. The empirical results in Model 1 and Model 2 are similar, indicating that the results are relatively stable. In Model 1, the result shows that the coefficient of ASSs is 4.463 with a significance level of $1 \%$, implying that ASSs have a significant, positive impact on the overall FSM operation of smallholder farmers. In Model 2, the result shows that the 
coefficient of agricultural socialized services is 4.411 with a significance level of $1 \%$; ASSs have a significant, positive impact on the overall FSM operation of smallholder farmers. The higher the level of ASSs, the larger the FSM of smallholder farmers, which confirms hypothesis 1 . The purchase of ASSs by smallholder farmers can effectively alleviate their labor, technical, and financial constraints, and provide external conditions for expanding their FSM operations.

Consistent with our findings, [44] found that the expansion of large farmlands through land consolidation can only be achieved by improving suitably scaled agricultural mechanization services. The authors of [7] revealed that the provision of agricultural mechanization in the form of services can push smallholder farmers to switch to larger farmland operations by farmland rent-in. Ref. [11] studied the complementarity effect of farmland and agricultural mechanization and found that the growing availability of agricultural mechanization tends to have reduce small-sized farmlands in Asia. This finding supports the role of AM services in speeding up farmland transfer-in to create large farmlands. The authors of [45] revealed that, in the effort to move into operating moderate-scale agriculture, the complementarity of ASS with respect to mechanization and farmland rent-in is critical. It was stated in [46], however, that the establishment of large farms induced by land transfer and AM services resulted in a decline in labor-intensive crop production yet enhanced reduced-labor crop growth. This implies that the development of ASSs should consider such types of bottlenecks. Therefore, in the process of agricultural scale management, it is necessary to not only consider how farmland consolidation is influenced by ASSs to create large farms but also to evaluate the outcomes of FSM operations, such as reduced input costs and enhancing agricultural productivity.

Table 2. The overall impact of ASS on the FSM operation of small farmers.

\begin{tabular}{|c|c|c|c|c|}
\hline \multirow[t]{2}{*}{ Variables } & \multicolumn{2}{|c|}{$\begin{array}{c}\text { Model } 1 \\
\text { OLS + Robust Standard } \\
\text { Error }\end{array}$} & \multicolumn{2}{|c|}{$\begin{array}{c}\text { Model } 2 \\
\text { Weight Least Squares } \\
\text { (WLS) }\end{array}$} \\
\hline & Coefficient & S.E. & Coefficient & S.E. \\
\hline ASS & $4.463^{* * *}$ & 1.302 & $4.411^{* * *}$ & 1.107 \\
\hline Age & $-0.058 * * *$ & 0.021 & $-0.052^{* *}$ & 0.023 \\
\hline Education level & $0.142 * *$ & 0.063 & $0.153^{* *}$ & 0.068 \\
\hline Physical health & 0.033 & 0.190 & -0.032 & 0.206 \\
\hline Population structure & 0.436 & 0.580 & 0.397 & 0.609 \\
\hline Income level & $1.492 * * *$ & 0.125 & $1.481^{* * *}$ & 0.151 \\
\hline Agricultural production income & $5.161^{* * *}$ & 0.649 & $5.305^{* * *}$ & 0.706 \\
\hline Human capital & $1.610^{* * *}$ & 0.458 & $1.621^{* * *}$ & 0.436 \\
\hline Fragmentation degree of farmland & $-0.457^{* * *}$ & 0.178 & $-0.429 * * *$ & 0.151 \\
\hline Farmland leveling & -0.110 & 0.830 & -0.116 & 0.624 \\
\hline Farmland fertility status & -0.110 & 0.254 & -0.176 & 0.237 \\
\hline Geographic location & 0.149 & 0.150 & 0.1517 & 0.115 \\
\hline Local farmland transfer price & $3.384 * *$ & 1.706 & $3.4814^{* * *}$ & 1.277 \\
\hline Agricultural infrastructure level & $1.468^{* * *}$ & 0.485 & $1.529 * * *$ & 0.466 \\
\hline Constant term & $-53.650 * * *$ & 8.088 & $-53.886^{* * *}$ & 7.178 \\
\hline
\end{tabular}

Note: ${ }^{* *},{ }^{* *}$ indicate statistical significance at the level of $5 \%$, and $1 \%$, respectively.

Among the control variables, age, education level, income level, the proportion of agricultural production income, human capital, degree of farmland fragmentation, local farmland transfer price, and agricultural infrastructure level also have an impact on the FSM of smallholder farmers. Age and the farmland fragmentation degree appear to have a negative impact on the FSM of small farmers.

\subsection{The Impact of ASS for Various Steps in Agricultural Practices on the FSM of Smallholder Farmers}

The impact of ASSs on agricultural practices include tillage, transplanting, cropprotection (including pesticide, herbicide, and fertilizer application), and harvesting on the 
FSM of smallholder farmers is presented in Table 3. The weighted least squares method (WLS) is still used to estimate from Model 3 to Model 6. The results show that the impact of ASSs on various agricultural practices on the FSM of smallholder farmers is different. The ASSs for transplanting, crop protection, and harvesting have a significant impact on smallholder farmers' FSM operations. However, as can be seen in Table 3 of Model 3, the impact of ASSs for tillage operation on the FSM of smallholder farmers is not significant for two fundamental reasons: (1) in areas with small household size, almost all of the smallholder farmers conduct farmland tilling operations using animal power; (2) in areas with large household sizes, small farmers buy small agricultural machines by themselves. This is because the cost of purchasing small agricultural machines (3000-5000) is far lower than the cost of renting machines through an ASS. Moreover, small agricultural machines owned by the farmers provide a long service life (3-5 years), high operation efficiency (about $1 \mathrm{mu} / \mathrm{hr}$ ), whereas the agricultural machinery socialized service cost is 100 yuan/ mu. These are the two critical factors that discourage farmers from acquiring agricultural machines in the form of ASS.

Table 3. The impact of ASSs for agricultural practices (tillage, transplanting, crop-protection, and harvest) on the FSM of smallholder farmers.

\begin{tabular}{|c|c|c|c|c|c|c|c|c|}
\hline \multirow{2}{*}{ Variables } & \multicolumn{2}{|c|}{$\begin{array}{l}\text { Model } 3 \\
\text { Tillage }\end{array}$} & \multicolumn{2}{|c|}{$\begin{array}{c}\text { Model } 4 \\
\text { Transplanting }\end{array}$} & \multicolumn{2}{|c|}{$\begin{array}{c}\text { Model } 5 \\
\text { Crop-Protection }\end{array}$} & \multicolumn{2}{|c|}{$\begin{array}{l}\text { Model } 6 \\
\text { Harvest }\end{array}$} \\
\hline & Coefficient & S.E. & Coefficient & S.E. & Coefficient & S.E. & Coefficient & S.E. \\
\hline ASS & -0.300 & 1.485 & $8.337^{* * *}$ & 1.780 & $11.435^{* * *}$ & 2.457 & $6.455^{* * *}$ & 1.521 \\
\hline Age & -0.034 & 0.023 & 0.012 & 0.021 & 0.0115 & 0.019 & -0.013 & 0.022 \\
\hline Education level & $0.185^{* * *}$ & 0.071 & $0.234^{* * *}$ & 0.067 & $0.1684^{* * *}$ & 0.064 & $0.234^{* * *}$ & 0.069 \\
\hline Physical health & -0.259 & 0.210 & $-0.470^{* *}$ & 0.201 & $-0.534^{* * *}$ & 0.191 & -0.103 & 0.209 \\
\hline Population structure & 0.623 & 0.646 & -0.170 & 0.622 & -0.051 & 0.511 & 0.291 & 0.645 \\
\hline Income level & $1.400^{* * *}$ & 0.160 & $1.242 * * *$ & 0.149 & $1.262 * * *$ & 0.150 & $1.393^{* * *}$ & 0.155 \\
\hline Agricultural production income & $6.094^{* * *}$ & 0.730 & $6.074^{* * *}$ & 0.755 & $6.217^{* * *}$ & 0.716 & $5.516^{* * *}$ & 0.738 \\
\hline Human capital & $2.056^{* * *}$ & 0.453 & $1.861^{* * *}$ & 0.403 & $2.188^{* * *}$ & 0.385 & $2.110^{* * *}$ & 0.435 \\
\hline $\begin{array}{l}\text { Fragmentation degree of } \\
\text { farmland }\end{array}$ & $-0.322^{* *}$ & 0.147 & $-0.424^{* * *}$ & 0.139 & $-0.303^{* * *}$ & 0.115 & $-0.500^{* * *}$ & 0.149 \\
\hline Farmland leveling & 0.194 & 0.655 & -0.160 & 0.616 & $0.925 *$ & 0.556 & -0.415 & 0.694 \\
\hline Farmland fertility status & -0.201 & 0.244 & $-0.621^{* * *}$ & 0.219 & $-0.671^{* * *}$ & 0.205 & $-0.457 *$ & 0.234 \\
\hline Geographic location & 0.093 & 0.118 & 0.133 & 0.118 & -0.024 & 0.102 & $0.285^{* *}$ & 0.128 \\
\hline Local farmland transfer price & $8.498^{* * *}$ & 1.196 & 1.847 & 1.392 & 1.466 & 1.445 & $3.132^{* *}$ & 1.408 \\
\hline Agricultural infrastructure level & $1.031^{* *}$ & 0.498 & $1.687^{* * *}$ & 0.438 & $1.306^{* * *}$ & 0.438 & $1.883^{* * *}$ & 0.473 \\
\hline Constant term & $-59.651^{* * *}$ & 7.707 & $-20.708^{* *}$ & 8.736 & $-18.563^{* *}$ & 8.860 & $-33.521^{* * *}$ & 8.337 \\
\hline
\end{tabular}

Note: ${ }^{*},{ }^{* * * *}$ indicate statistical significance at the level of $10 \%, 5 \%$, and $1 \%$, respectively.

\subsection{The Impact of ASSs on the Farmland Transfer Behavior of Small Farmers}

In China, under the institutional arrangement of the household responsibility system, farmland transfer is one of the critical pathways for smallholder farmers to expand the scale of agricultural operations. Farmland is transferred-in to collectives or to other small farmers on the basis of enhancing the scale of operation and reducing farmland fragmentation. The farmland transfer behavior of smallholder farmers is divided into two kinds: (1) farmland transfer-in (Yes, farmers transfer-in farmlands), where farmers rent land to expand their scale of operation; (2) farmland is maintained as it is (No, farmers don't want to transfer-in farmlands), where farmers keep their original farmland without transferring it to other farmlands. Thus, we use a binary logit regression to examine the impact of the overall development level of ASSs and the level of ASSs for agricultural practices, such as tillage, sow, crop protection, and harvesting, on the farmland transfer behavior of smallholder farmers. The estimated results are presented in Table 4.

The results of Model 7 show that the coefficient of overall ASSs is 1.266 with a significance level of $1 \%$, indicating that, overall, ASSs have a significant, positive impact on the farmland behavior of small farmers, and implying that the higher the overall level of ASSs, the greater the farmland transfer behavior of small farmers. Therefore, developing 
ASSs is an important way to encourage smallholder farmers to expand their FSM and enhance the management scale of overall agricultural operations. The ASSs for each agricultural practice also have a significant, positive impact on the farmland transfer behavior of smallholder farmers in China.

Table 4. The impact of ASSs on farmland transfer behavior of smallholder farmers.

\begin{tabular}{|c|c|c|c|c|c|c|c|c|c|c|}
\hline \multirow[t]{2}{*}{ Variables } & \multicolumn{2}{|c|}{$\begin{array}{l}\text { Model } 7 \\
\text { (Whole) }\end{array}$} & \multicolumn{2}{|c|}{$\begin{array}{l}\text { Model } 8 \\
\text { (Tillage) }\end{array}$} & \multicolumn{2}{|c|}{$\begin{array}{c}\text { Model } 9 \\
\text { (Transplanting) }\end{array}$} & \multicolumn{2}{|c|}{$\begin{array}{c}\text { Model } 10 \\
\text { (Crop-protection) }\end{array}$} & \multicolumn{2}{|c|}{$\begin{array}{c}\text { Model } 1 \\
\text { (Harvest) }\end{array}$} \\
\hline & Coefficient & S.E. & Coefficient & S.E. & Coefficient & S.E. & Coefficient & S.E. & Coefficient & S.E. \\
\hline ASS & $1.266^{* * *}$ & 0.470 & $1.640^{* * *}$ & 0.627 & $1.331 * *$ & 0.616 & $3.448^{* * *}$ & 0.903 & $2.174^{* * *}$ & 0.686 \\
\hline Age & -0.005 & 0.010 & -0.005 & 0.010 & -0.004 & 0.010 & -0.007 & 0.010 & -0.002 & 0.010 \\
\hline Education level & -0.016 & 0.030 & -0.019 & 0.030 & -0.014 & 0.030 & -0.010 & 0.030 & -0.015 & 0.030 \\
\hline Physical health & $-0.161 *$ & 0.089 & $-0.162 *$ & 0.089 & $-0.171 *$ & 0.088 & $-0.149 *$ & 0.089 & $-0.148 *$ & 0.089 \\
\hline $\begin{array}{c}\text { Population } \\
\text { structure }\end{array}$ & $1.564^{* * *}$ & 0.338 & $1.595 * * *$ & 0.334 & $1.546^{* * *}$ & 0.335 & $1.680^{* * *}$ & 0.339 & $1.535^{* * *}$ & 0.332 \\
\hline Income level & $0.639 * * *$ & 0.078 & $0.663^{* * *}$ & 0.079 & $0.627 * * *$ & 0.078 & $0.649^{* * *}$ & 0.079 & $0.645^{* * *}$ & 0.078 \\
\hline $\begin{array}{l}\text { Agricultural } \\
\text { income }\end{array}$ & $2.170 * * *$ & 0.332 & $2.322 * * *$ & 0.327 & $2.200^{* * *}$ & 0.332 & $2.140^{* * *}$ & 0.329 & $2.147^{* * *}$ & 0.329 \\
\hline $\begin{array}{l}\text { Human capital } \\
\text { Fragmentation }\end{array}$ & $0.584^{* * *}$ & $(0.190)$ & $0.586^{* * *}$ & 0.190 & $0.582^{* * *}$ & 0.190 & $0.622^{* * *}$ & 0.192 & $0.674^{* * *}$ & 0.195 \\
\hline $\begin{array}{l}\text { degree of } \\
\text { farmland }\end{array}$ & $0.202^{* * *}$ & 0.072 & $0.210^{* * *}$ & 0.072 & $0.184^{* * *}$ & 0.070 & $0.219^{* * *}$ & 0.073 & $0.197^{* * *}$ & 0.071 \\
\hline Farmland leveling & $0.494 *$ & 0.271 & $0.571^{* *}$ & 0.266 & $0.605^{* *}$ & 0.265 & $0.827^{* * *}$ & 0.270 & 0.302 & 0.287 \\
\hline $\begin{array}{c}\text { Farmland fertility } \\
\text { status }\end{array}$ & -0.026 & 0.103 & -0.003 & 0.104 & -0.030 & 0.102 & 0.017 & 0.104 & -0.025 & 0.103 \\
\hline $\begin{array}{l}\text { Geographic } \\
\text { location }\end{array}$ & -0.042 & 0.050 & -0.044 & 0.050 & -0.070 & 0.049 & $-0.085^{*}$ & 0.050 & 0.005 & 0.054 \\
\hline $\begin{array}{l}\text { Local farmland } \\
\text { transfer price } \\
\text { Agricultural }\end{array}$ & -0.015 & 0.523 & 0.607 & 0.457 & 0.131 & 0.524 & -0.780 & 0.603 & -0.216 & 0.536 \\
\hline $\begin{array}{c}\text { Infrastructure } \\
\text { level }\end{array}$ & $0.664^{* * *}$ & 0.205 & $0.726^{* * *}$ & 0.212 & $0.610^{* * *}$ & 0.201 & $0.575^{* * *}$ & 0.200 & $0.693^{* * *}$ & 0.206 \\
\hline Constant term & $-16.120^{* * *}$ & 3.251 & $-14.687^{* * *}$ & 3.131 & $-10.337^{* * *}$ & 3.429 & -5.786 & 3.725 & $-9.901^{* * *}$ & 3.274 \\
\hline
\end{tabular}

Note: $* * *, * * *$ indicate statistical significance at the level of $10 \%, 5 \%$, and $1 \%$, respectively, and the robust standard errors are in parentheses.

\section{Conclusions and Recommendation}

Farmland transfer is one of the most critical paths for China to realize moderate and large-scale agriculture. This study aimed to empirically investigate the impact of ASSs on FSM operations of smallholder farmers and the impact of the ASSs for tilling, transplanting, crop-protection, and harvest operations on the FSM of small farmers, and to explore the ways in which smallholder farmers' farmland transfer behavior (transfer-in and transferout) is affected by ASSs. This paper uses sample data collected from 741 small farmers in eight counties located in Hunan, Jiangxi, and Zhejiang provinces. The findings showed that the current average scale of farmland operation of smallholder farmers in southern China is $7.275 \mathrm{mu}$. The proportion of smallholder farmers exhibiting farmland transfer behavior is $52.45 \%, 40.53 \%$ having transferred farmland.

The empirical findings generally showed that the availability of ASSs has a significant impact on the promotion of smallholder farmers' FSM operations. Of the ASSs for particular agricultural practices, only ASSs for tillage have an insignificant impact on the scale of farmland operation for smallholder farmers and for two fundamental reasons. Firstly, in areas with small household sizes, almost all smallholder farmers conduct the farmland tilling operation using animal power. Secondly, in areas with large household sizes, smallholder farmers prefer to buy small agricultural machines rather than renting them in the form of ASSs because the cost of renting the machinery through ASSs is higher than the cost of purchasing it for themselves. However, ASSs for harvest, crop protection, and harvesting have a significant impact in terms of promoting the scale of farmland 
operations of smallholder farmers and promoting farmland transfer behavior. The total of (whole) ASSs for tillage, transplanting, crop protection, and harvesting has a significant impact on smallholder farmers' FSM in China.

The findings from this study have policy implications for the establishment of moderatescale agriculture. The positive and significant impact of the ASSs on the FSM of smallholder farmers implies the necessity of a policy intervention to realize the establishment of an appropriate scale of farmland by incorporating ASSs for smallholder farmers. The government and related organizations should put forward supporting measures, such as subsidies to encourage the expansion of innovative ASSs.

The development of ASSs should be taken as one of the main directions for promoting agricultural and rural modernization, strengthening classified guidance, and promoting orderly rural development. The government should strengthen pilot and demonstration projects and carry out trials to innovate ASSs. Incentive-based policies and strategies, such as financial support policies and preferential tax policies, should be implemented. The policies should strengthen both the supply and demand sides of ASSs.

This study is limited to examining the impact of ASSs on the FSM operation of smallholder farmers. Such impacts may occur due to factors such as farmers' income status, off-farm employment opportunities for rural labor, farmland rights policies, and the topography of the farmland areas. Future studies addressing these factors in the study of farmland transfer would contribute to the establishment of moderate and large-scale agricultural operations. Our study only focuses on smallholder rice farmers and data collected from eight counties from the three provinces in the southern rice-growing region of China. Studies on other grains, such as wheat, corn, and soybeans, are crucial to gain better knowledge of the heterogeneous effects of ASSs on FSM in a broader context.

Author Contributions: Conceptualization, B.C. and M.A.; methodology, B.C.; software, B.C.; validation, B.C., F.S., M.A. and Y.H.; formal analysis, B.C. and F.S.; investigation, B.C., F.S. and M.A.; resources, B.C. and Y.H.; data curation, B.C. and F.S.; writing-original draft preparation, M.A.; writing-review and editing, M.A.; visualization, B.C.; supervision, Y.H.; project administration, Y.H.; funding acquisition, Y.H. All authors have read and agreed to the published version of the manuscript.

Funding: This research was funded by a key project of the Hunan Provincial Social Science Achievements Evaluation Committee, China (Grant No. XSP21ZDI023).

Institutional Review Board Statement: Not applicable.

Informed Consent Statement: Not applicable.

Data Availability Statement: Not applicable.

Acknowledgments: Special thanks are given to the farmers who were eager to cooperate in the survey.

Conflicts of Interest: The authors declare no conflict of interest.

\section{References}

1. de Roest, K.; Ferrari, P.; Knickel, K. Specialisation and economies of scale or diversification and economies of scope? Assessing different agricultural development pathways. J. Rural Stud. 2018, 59, 222-231. [CrossRef]

2. Hoang, V.-N.; Nguyen, T.T.; Wilson, C.; Ho, T.Q.; Khanal, U. Scale and scope economies in small household rice farming in Vietnam. J. Integr. Agric. 2021, 20, 3339-3351. [CrossRef]

3. Rogers, S.; Wilmsen, B.; Han, X.; Wang, Z.J.-H.; Duan, Y.; He, J.; Li, J.; Lin, W.; Wong, C. Scaling up agriculture? The dynamics of land transfer in inland China. World Dev. 2021, 146, 105563. [CrossRef]

4. Kuroda, Y. Impacts of economies of scale and technological change on agricultural productivity in Japan. J. Jpn. Int. Econ. 1989, 3, 145-173. [CrossRef]

5. Mpanga, I.K.; Schuch, U.K.; Schalau, J. Adaptation of resilient regenerative agricultural practices by small-scale growers towards sustainable food production in north-central Arizona. Curr. Res. Environ. Sustain. 2021, 3, 100067. [CrossRef]

6. Jiang, Y.; Tang, Y.T.; Long, H.; Deng, W. Land Consolidation: A Comparative Research between Europe and China. Land Use Policy 2022, 112, 105790. [CrossRef]

7. Marrit Van Den Berg, M.; Hengsdijk, H.; Wolf, J.; Van Ittersum, M.K.; Wang, G.; Roetter, R.P. The impact of increasing farm size and mechanization on rural income and rice production in Zhejiang province, China. Agric. Syst. 2007, 94, 841-850. [CrossRef] 
8. Gao, J.; Song, G.; Sun, X. Does labor migration affect rural land transfer? Evidence from China. Land Use Policy 2020, 99 , 105096. [CrossRef]

9. Van Loon, J.; Woltering, L.; Krupnik, T.J.; Baudron, F.; Boa, M.; Govaerts, B. Scaling agricultural mechanization services in smallholder farming systems: Case studies from sub-Saharan Africa, South Asia, and Latin America. Agric. Syst. 2020, 180, 102792. [CrossRef]

10. Li, F.; Feng, S.; Lu, H.; Qu, F.; D’Haese, M. How do non-farm employment and agricultural mechanization impact on large-scale farming? A spatial panel data analysis from Jiangsu Province, China. Land Use Policy 2021, 107, 105517. [CrossRef]

11. Yamauchi, F. Rising real wages, mechanization and growing advantage of large farms: Evidence from Indonesia. Food Policy 2016, 58, 62-69. [CrossRef]

12. Guo, G.; Wen, Q.; Zhu, J. The Impact of Aging Agricultural Labor Population on Farmland Output: From the Perspective of Farmer Preferences. Math. Probl. Eng. 2015, 2015, 730618. [CrossRef]

13. Zhou, Y.; Li, X.; Liu, Y. Rural land system reforms in China: History, issues, measures and prospects. Land Use Policy 2020, 91 , 104330. [CrossRef]

14. Knight, J.; Deng, Q.; Li, S. The puzzle of migrant labour shortage and rural labour surplus in China. China Econ. Rev. 2011, 22, 585-600. [CrossRef]

15. Tan, S.; Heerink, N.; Qu, F. Land fragmentation and its driving forces in China. Land Use Policy 2006, 23, 272-285. [CrossRef]

16. Gong, B. Agricultural reforms and production in China: Changes in provincial production function and productivity in 1978-2015. J. Dev. Econ. 2018, 132, 18-31. [CrossRef]

17. Hong, T.; Yu, N.; Mao, Z.; Zhang, S. Government-driven urbanisation and its impact on regional economic growth in China. Cities 2021, 117, 103299. [CrossRef]

18. Su, B.; Li, Y.; Li, L.; Wang, Y. How does nonfarm employment stability influence farmers' farmland transfer decisions? Implications for China's land use policy. Land Use Policy 2018, 74, 66-72. [CrossRef]

19. Hong, Z.; Sun, Y. Power, capital, and the poverty of farmers' land rights in China. Land Use Policy 2020, 92, 104471. [CrossRef]

20. Wang, Y.; Li, X.; He, H.; Xin, L.; Tan, M. How reliable are cultivated land assets as social security for Chinese farmers? Land Use Policy 2020, 90, 104318. [CrossRef]

21. Wang, H.; He, C.; Li, W.; Nie, X.; Zhong, H.; Wen, L. Will transferable development rights (TDR) increase regional economic imbalance? - A quota transaction case of cultivated land conversion and reclamation in Guangxi, China. Habitat Int. 2020, 104, 102254. [CrossRef]

22. Li, C.; Ma, W.; Mishra, A.K.; Gao, L. Access to credit and farmland rental market participation: Evidence from rural China. China Econ. Rev. 2020, 63, 101523. [CrossRef]

23. Yan, J.; Yang, Y.; Xia, F. Subjective land ownership and the endowment effect in land markets: A case study of the farmland "three rights separation" reform in China. Land Use Policy 2021, 101, 105137. [CrossRef]

24. Paudel, G.P.; Kc, D.B.; Rahut, D.B.; Khanal, N.P.; Justice, S.E.; McDonald, A.J. Smallholder farmers' willingness to pay for scale-appropriate farm mechanization: Evidence from the mid-hills of Nepal. Technol. Soc. 2019, 59, 101196. [CrossRef]

25. Zhang, X.; Yang, J.; Thomas, R. Mechanization outsourcing clusters and division of labor in Chinese agriculture. China Econ. Rev. 2017, 43, 184-195. [CrossRef]

26. Milczarek-Andrzejewska, D.; Zawalinska, K.; Czarnecki, A. Land-use conflicts and the Common Agricultural Policy: Evidence from Poland. Land Use Policy 2018, 73, 423-433. [CrossRef]

27. Qiu, T.; Luo, B. Do small farms prefer agricultural mechanization services? Evidence from wheat production in China. Appl. Econ. 2021, 53, 2962-2973. [CrossRef]

28. Qing, Y.; Chen, M.; Sheng, Y.; Huang, J. Mechanization services, farm productivity and institutional innovation in China. China Agric. Econ. Rev. 2019, 11, 536-554. [CrossRef]

29. Yang, J.; Huang, Z.; Zhang, X.; Reardon, T. The Rapid Rise of Cross-Regional Agricultural Mechanization Services in China. Am. J. Agric. Econ. 2013, 95, 1245-1251. [CrossRef]

30. Ma, L.; Long, H.; Tu, S.; Zhang, Y.; Zheng, Y. Farmland transition in China and its policy implications. Land Use Policy 2020, 92, 104470. [CrossRef]

31. Qiu, T.; Shi, X.; He, Q.; Luo, B. The paradox of developing agricultural mechanization services in China: Supporting or kicking out smallholder farmers? China Econ. Rev. 2021, 69, 101680. [CrossRef]

32. Olmstead, A.L.; Rhode, P.W. Reshaping the landscape: The impact and diffusion of the tractor in american agriculture, 1910-1960. J. Econ. Hist. 2001, 61, 663-698. [CrossRef]

33. Song, J.; Zhenglin, C.; Han, L. A comparative study on the impact of agricultural socialized services on land management: An empirical study based on CHIP microdata. J. Agrotech. Econ. 2016, 11, 4-13.

34. Weng, Z.; Xu, J. Agricultural machinery socialization service and farmland transfer: Evidence from small-scale rice farmers. J. Agric. For. Econ. Manag. 2019, 18, 1-11.

35. Yang, Z.; Rao, F.; Zhu, P. The impact of agricultural socialization service on land scale Management: An empirical analysis based on the perspective of farmers' land transfer. Chin. Rural Econ. 2019, 3, 82-95.

36. Qian, W.; Zheng, L. The impact of migrant workers on farmers' agricultural production-Research Status and prospect. China Rural Surv. 2011, 1, 31-38. 
37. Wu, L.; Li, G.; Zhou, X. Change of factor endowment and choice of Agricultural growth path in China. China Popul. Resour. Environ. 2015, 25, 144-152.

38. Hayami, Y.; Ruttan, V.W. Factor Prices and Technical Change in Agricultural Development: The United States and Japan, 1880-1960. J. Political Econ. 1970, 78, 1115-1141. [CrossRef]

39. Jiao, C.; Dong, L. From "overdensity" to "mechanization": The process, dynamics, and impact of Agricultural mechanization revolution in China (1980-2015). Manag. World 2018, 34, 173-190.

40. Cao, Y.; Hu, J. Agricultural mechanization under the household land contract system in China: Based on the survey data of 17 provinces in China. Chin. Rural Econ. 2010, 10, 57-65.

41. Pingali, P. Agricultural mechanization: Adoption patterns and economic impact. Handb. Agric. Econ. 2007, 3, $2779-2805$.

42. Bardhan, P.; Udry, C. Development Microeconomics; Oxford University Press (OUP): Oxford, UK, 1999.

43. Deininger, K.; Jin, S. Land Sales and Rental Markets in Transition: Evidence from Rural Vietnam. Oxf. Bull. Econ. Stat. 2007, 70, 67-101. [CrossRef]

44. Wang, X.; Yamauchi, F.; Huang, J.; Rozelle, S. What constrains mechanization in Chinese agriculture? Role of farm size and fragmentation. China Econ. Rev. 2020, 62, 101221. [CrossRef]

45. Wang, X.; Yamauchi, F.; Otsuka, K.; Huang, J. Wage Growth, Landholding, and Mechanization in Chinese Agriculture. World Dev. 2016, 86, 30-45. [CrossRef]

46. Qiao, F. Increasing wage, mechanization, and agriculture production in China. China Econ. Rev. 2017, 46, 249-260. [CrossRef] 